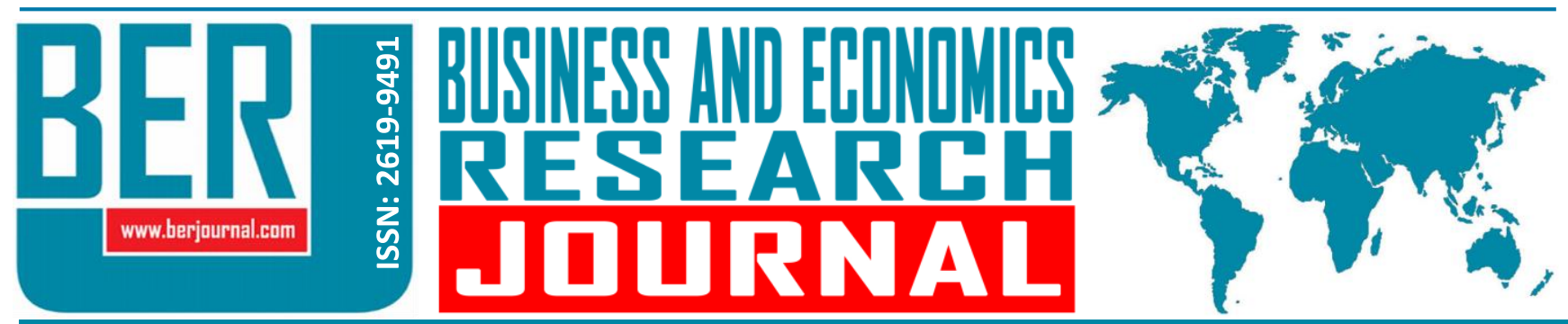

Business and Economics Research Journal Vol. 11, No. 4, 2020, pp. 1119-1132 doi: 10.20409/berj.2020.302

\section{Algılanan Örgütsel Adaletin Çalışanların İş Etiğine Yönelik Tutumları Üzerindeki Etkisi: Özel Sektör Üzerinde Görgül Bir Araştırma}

\begin{abstract}
Ahmet Mumcu ${ }^{\mathrm{a}}$
Öz: Bu çalışma, algılanan örgütsel adaletin çalışanların iş etiğine yönelik tutumları üzerindeki etkisini araştırmak amacıyla gerçekleştirilmiştir. Çalışmada öncelikle algılanan örgütsel adalet ve iş etiği kavramlarına teorik olarak yer verilmiştir. Daha sonra adalet ve etik bağlamında örgütsel adalet ve iş etiği arasındaki ilişki nitel ve nicel araştırmalar temelinde ele alınmıştır. Çalışmada özel sektörde faaliyet gösteren işletmelerde çalışan 346 personel üzerinde saha araştırması yapılmıştır. Araştırmadan elde edilen verilerin analizinde Yapısal Eşitlik Modeli (YEM) kullanılmıştır. Araştırma verilerinin değerlendirilmesi sonucunda algılanan dağıtım adaletinin ve algılanan etkileşim adaletinin çalışanların iş etiğine yönelik tutumları üzerinde anlamlı bir etkiye sahip olmadığı tespit edilmiştir. Buna karşın algılanan prosedür adaletinin, çalışanların iş etiğine yönelik tutumları üzerinde pozitif yönlü bir etkiye sahip olduğu tespit edilmiştir.
\end{abstract}

\section{The Effect of Perceived Organizational Justice on Employees' Attitudes to Business Ethics: An Empirical Research on Private Sector}

\begin{abstract}
This study is conducted to investigate the effect of perceived organizational justice on attitudes towards employees' business ethics. In the study, the concepts of organizational justice and business ethics, which are perceived, are given theoretically. Later, in the context of justice and ethics, the relationship between organizational justice and business ethics is addressed on the basis of qualitative and quantitative studies. Field research is carried out on 346 personnel working at businesses operating in private sector. Structural Equation Model (SEM) is used in the analysis of the data obtained from the research. As a result of the evaluation of the research data, it is found out that perceived distribution justice and perceived interactional justice don't have a significant effect on the attitudes of employees towards business ethics. On the other hand, it is also found out that perceived procedural justice has a positive effect on employees' attitudes towards business ethics.
\end{abstract}

Anahtar Sözcükler: Etik, İş Etiği, Örgütsel Adalet

JEL: D23, M10

$\begin{array}{ll}\text { Geliş } & : 28 \text { Mayıs } 2020 \\ \text { Düzeltme } & : 09 \text { Temmuz } 2020 \\ \text { Kabul } & : 18 \text { Eylül } 2020 \\ \text { Tür } & : \text { Araştırma }\end{array}$

Keywords: Ethic, Business Ethic, Organizational Justice

JEL: D23, M10

$\begin{array}{ll}\text { Received } & : 28 \text { May } 2020 \\ \text { Revised } & : \text { 09 July } 2020 \\ \text { Accepted } & : \text { 18 September } 2020 \\ & \\ \text { Type } & : \text { Research }\end{array}$




\section{Giriş}

Küreselleşme ile birlikte iş etiği, işletmeler için stratejik öneme sahip bir kavram olarak yeni bir boyut kazanmıştır. İ̧ dünyasında günümüzde daha çok sayıda işletme etik kurallar belirlemekte, bölgesel ya da ulusal bazda sosyal sorumluluk programları uygulamaktadır (Aleksic, 2007). Aynı zamanda son yıllarda yaşanan büyük iş skandalları ve krizler nedeniyle, iş etiği sadece bilim insanlarının değil aynı zamanda işletme sahipleri ve yöneticilerin de özellikle dikkatini çekmektedir. Bu önemli alanda disiplinler arası bilimsel bilgiyi artırmak amacı ile araştırmalar yapılmakta ve iş etiğinin farklı yönlerini teorik ve ampirik olarak ortaya koymak için çabalar sarf edilmektedir (Klopatan vd., 2020: 32).

Kavramın disiplinler arası bir yapıda bulunması nedeniyle çalışanların etik ya da etik dışı davranışını etkileyen birçok faktör bulunmaktadır. Bu faktörler kişiye, eyleme, örgüte ve çevreye ilişkin faktörler olarak dört ana başlık altında değerlendirilmektedir. Kişiye ilişkin etmenler arasında kişinin değerlerinin, tecrübelerinin, iş pozisyonu ve kıdeminin, demografik özelliklerinin var olduğu görülmektedir. Örgütsel etmenler arasında etik kodların, örgütün yönetim tarzı ve felsefesinin, örgüt kültürünün etkili olduğu tespit edilmektedir. Eyleme ilişkin etmenlerde davranışın açık bir etik ihlali olup olmadığı yoksa gri bir alanda mı yer aldığı, etkilenen kişi ve grupların kim olduğu önemli bir yere sahiptir. Son olarak dış faktörler olarak ekonomik, siyasal, sosyal ve kültürel çevrenin çalışanın etik davranış üzerinde etkisi olduğu görülmektedir (Arslan ve Berkman, 2009).

İs etiğine yönelik tutumu ve etik ya da etik dışı karar verme sürecini etkileyen faktörlerden birisinin de örgütlerdeki adalet algısının olabileceği düşünülmektedir. Bu açıdan çalışmada etik ve adalet temelinde algılanan örgütsel adalet ve iş etiği kavramları ele alınmıştır. Kavramların ortak bir çalışmada bir araya getirilmesinde çeşitli sebepler bulunmaktadır. İlk olarak süreç ve sonuçlarına ait roller yönüyle baktığımızda etik ve adaletin birbirine paralel iki kavram olduğu görülmektedir. İincisi hem etik hem de adaletin birbiri üzerine inşa edileceği güçlü teorik temelleri vardır. Bu kısım kavramlar alası ilişkiler bölümünde detaylı bir şekilde ele alınmaktadır. Üçüncüsü bu teorik temeller araştırmacıları örgütsel ortamların ayrı ancak tamamlayıcı yönlerine odaklanmaya yönlendirmektedir. Bu yönlendirme vasıtasıyla etik araştırmalar, örgütlerde oluşan algıların iş etiğine yönelik tutumları nasıl etkilediğine, iş etiğine yönelik tutumlarında bireylerin inanç ve davranışlarına nasıl etki ettiğine odaklanmaktadır (Schminke vd., 1997).

Yöneticiler iş hayatında karşılaştığı en önemli ahlaki sorunları, adaletsiz yönetim, işe alım ve terfilerde yaşanan adaletsizlikler, ayrımcılık ve emek sömürüsü olarak sıralamışlardır (Torlak vd., 2018: 47). İ̧̧ hayatında faaliyet gösteren bir iş adamının da aldığı kararlarda adil olması koşuluyla etik olduğu söylenebilmektedir. Bu açıdan adaleti, birçok çağrışımı olan etik bir kavram olarak tanımlamak mümkündür (McGowan, 1990: 899). Yaşadığımız toplumsal hayatın belirli oranda yansıması olarak görülen örgütlerde adalet kavramı, her geçen gün iş dünyası ve çalışma hayatındaki önemini daha da artırmaktadır. Çalışanda oluşan adaletsizlik algısının, üretkenlik karşıtı iş davranışı, örgütsel sapma davranışları, zarar verici iş davranışları, sapkın davranışlar gibi olumsuz sonuçlara neden olabildiği çeşitli ampirik araştırmalarla ortaya konmuştur (Skarlicki ve Folger, 1997; Jawahar, 2002; Oge vd., 2015; Işıkay, 2019).

Bu çalışmada ise bu kavramlardan daha kapsamlı olmakla birlikte hem örgüt hem de birey açısından önemli düzeyde etkileri olan iş etiği kavramı ele alınmıştır. Bu çalışmada adalet ve etik araştırmalarına farklı bir perspektiften yaklaşıımıştır. Literatürde kavramlar arası ilişkilere ait güçlü bir teorik alt yapı bulunmasına rağmen adalet ve etik alanındaki çalışmaların nitel araştırmalar düzeyinde kaldığı görülmektedir. Bu çalışmada teoride ortaya konan bu ilişkinin görgül (ampirik) bir araştırma neticesinde hangi bulgulara ulaşacağı tespit edilecektir. Araştırmalarda etik olmanın bir parçası olarak genellikle adalet tanımlanmıştır ve etik kavramının kapsayıcı ve bütüncül bir kavram olması nedeniyle etik iklim, etik liderlik, etik kodlar, etik kültür, etik ilkeler vb. kavramların algılanan örgütsel adalet üzerindeki etkisini inceleyen birçok araştırma yapılmıştır (Kurgun vd., 2013; Torlak vd., 2018, Köksal 2018). Bu araştırmada ise algı, tutum ve davranış ilişkisi bağlamında algılanan örgütsel adaletin iş etiğine yönelik tutumun anlamlı bir öncülü olup olmadığı test edilecektir. Akademik yazına ilişkin veri tabanlarında ve dizinlerde (TR Dizin, EBSCO, Web of Science, ACAR Index ve Google Akademik) algılanan örgütsel adalet ve iş etiğine yönelik tutum arasındaki ilişkiyi inceleyen görgül bir araştırmaya rastlanmamıştır. Çalışma bu yönüyle bir anlamda kavramlar arası ilişkiyi ortaya koyan 
nicel bir araştırma olarak ilgili disipline öncü olacaktır. Ayrıca farkıı kültürel kodlara ve değerlere sahip Türk örneklemi üzerinde araştırmanın vereceği bulgular önem arz etmektedir. Ifade edilen durumlara bağı olarak araştırma, ilgili literatüre ve uygulayıcılara çeşitli katkılar sağlayacaktır. Kavramlar arası ilişkinin ele alınmasında araştırmamıza öncülük eden araştırma soruları şu şekilde sıralanabilir:

- Örgütte yaşanan adaletsizlikle birlikte çalışanların iş etiğine yönelik tutumları bu durumdan anlamlı bir şekilde etkileniyor mu?

- Örgütünde aynı iş pozisyonunda yer alan diğer çalışanlarla kendini kıyasladığında adil bir şekilde ödüllendirilmediğine inanan çalışanların iş etiğine yönelik tutumları bu durumdan etkileniyor mu?

- Örgütte işle ilgili alınan kararların tarafsız bir şekilde alınmadığını inanan çalışanların iş etiğine yönelik tutumları değişiklik gösteriyor mu?

- Örgütte yöneticisinin adil olmak adına bir çaba göstermediğini inanan çalışanların iş etiğine yönelik tutumları bu duruma bağlı olarak değişiklik gösteriyor mu?

- Çalışanların ifade edilen bu eşitsizlikleri düzeltmek adına etik olmayan yollara müracaat etme eğilimi artıyor mu?

Ifade edilen tüm bu araştırma soruları temelinde çalışmada algılanan örgütsel adaletin çalışanın iş etiğine yönelik tutumunu etkileyebilecek bir öncül olup olmadığı test edilecektir. Algılanan örgütsel adalet kavramı boyut düzeyine indirgenerek prosedür, etkileşim ve dağıım adaleti temelinde ele alınmıştır. Bu durum çalışmanın sonuçlarını detaylandırarak hangi adalet boyutunun iş etiğine yönelik tutumu etkileyebildiğini tespit etmemize imkân tanımaktadır. Çalışmada algılanan dağıtım adaletinin, algılanan prosedür adaletinin ve algılanan etkileşim adaletinin çalışanlarının iş etiğine yönelik tutumu üzerindeki etkisi belirlenecektir.

\section{Kavramsal Çerçeve}

\section{1. Örgütsel Adalet}

Adalet araştırmaları kökeni sosyal psikoloji disiplininde yatmaktadır. İş yerlerinde yaşanan gelişmeler ve uygulamalar örgütsel ortama özgü spesifik ilkelerin ve müdahalelerin geliştirilmesine yol açmıştır. Bu açıdan örgütsel adalet, işyerinde oluşan adalet algısı olarak tanımlanarak birçok araştırmaya konu olmuştur (Byrne ve Cropanzano, 2001). Örgütsel adalet, örgüt çalışanların için büyük ölçüde anlam ifade eden ve önemli düzeyde etkiye sahip olan örgütsel davranışın önemli konularından biridir. Örgütsel adalet, karar alma süreçlerinde ve sonuçlarındaki adaletin örgütteki çalışanlar tarafından nasıl algılandığını ifade etmektedir (Park ve Seo, 2019:179). Niehoff ve Moorman (1993) örgütsel adaleti, çalışanların işlerinde adil muamele görüp görmediklerine yönelik elde ettiği tespitler ve bu tespitlerin işle ilgili diğer örgütsel değişkenleri etkileme durumuyla ilişkili bir kavram olarak tanımlamaktadır. Cropanzano ve Ambrose (2015: 3)'a göre örgütsel adalet, çalışanların elde ettiği çıktılara (dağııım adaleti), kazanımların tahsis sürecine (prosedür adaleti) ve bu süreç boyunca maruz kaldığı kişisel muameleye (etkileşim adaleti) ilişkin adalet değerlendirmelerini içermektedir. Moorman (1991) araştırmasında dağıtım adaleti, prosedür adaleti ve etkileşim adaletinin örgütsel adaletin birbirleri ile ilişki içinde olan fakat birbirinden farklı yönlere sahip farklı üç boyutu olduğunu belirtmektedir. Bu açıklamalar temelinde örgütsel adaletin üç boyutlu bir kavram olduğu anlaşıımaktadır. Çalışmanın bu kısmında bu boyutlara ilişkin açıklamalara kısaca yer verilecektir.

\subsubsection{Dağıtım Adaleti}

Araştırmacılar tarafından örgütsel adalet için tanımlanan ilk boyut çalışanların elde ettiği çıktıların (ekonomik sonuçların) adil olup olmadığını değerlendirdiği dağıtım adaleti boyutu olmuştur. Dağıtım adaleti Adams (1965)'ın ortaya koyduğu eşitlik teorisinde temelinde oluşmuştur. Adams (1965)'a göre, insanlar kendi çabaları neticesinde elde ettiği sonuçlardan ziyade bu sonuçların adil olup olmadığı konusunda endişelenmektedir. Adams, bir sonucun adil olup olmadığını belirlemenin yolunun, çalışanın ortaya koyduğu katkıların (girdilerin) (ör. eğitim, zekâ ve tecrübe) çalışanın elde ettiği sonuca(çıktı) (ücret, prim, ödül) oranını 
hesaplamak ve daha sonra bu oranı benzer işi yapan başka bir çalışan ile karşılaştırmak olduğunu öne sürmektedir. Bu teori temelinde çalışan kendi kıyaslamasını yapmaktadır. Fakat bu kıyaslama oranlamanın tarafları itibari ile nesnel gibi gözükmekle birlikte bireyin sübjektif değerlendirmelerine çok açık olduğu aşikâr bir gerçek olarak kabul edilmektedir (Colquitt vd., 2001: 426). Lind ve Tyler (1988)'a göre dağıtım adaleti, katkılar, intiyaçlar ve eşitlik perspektifi açısından çalışanların detaylandırdığı çıktı adaleti olarak tanımlanmaktadır.

\subsubsection{Prosedür Adaleti}

Örgütsel adalet çalışmaları 1975'li yıllara kadar dağıtım adaletinden ibarettir (Colquitt vd., 2001: 426). Dağııım adaleti kavramından farklı olarak Thibaut ve Walker (1975) ortaya koyduğu prosedür adalet teorisi ile prosedür adaleti kavramını örgütsel adalet literatürüne kazandırmıştır. Kavram adalet bakış açısıyla örgütlerde elde edilen sonuçların belirlenmesinde kullanılan yöntemleri, mekanizmaları, araçları ve prosedürleri içermektedir (Cohen-Charash ve Spector, 2001). Prosedür adaleti; performans değerlendirme, maaş artışları ve terfileri, işe alım ve seçim süreçleri, kaynak tahsisi süreçlerinde kullanılan prosedürlere yönelik çalışanların adalet algılarını içermektedir. (Leventhal, 1980). Prosedür adaletine, kişinin örgütteki karar verme sürecinde sahip olduğu sesin (söz hakkının) derecesi ve örgütte karar aşamasında tutarlı bir şekilde kurallara uyulup uyulmaması örnek olarak verilebilmektedir (Scandura, 1999:28).

\subsubsection{Etkileşim Adaleti}

Örgütsel adalet literatürüne Bies ve Moag (1986) tarafından kazandırılan son boyut etkileşim adaleti olmuştur. Adaletin bu boyutu, örgütsel uygulamaların insani ilişkiler yönünü oluşturmaktadır. Bu nedenle, adaletin kaynağı ve alııısı arasındaki nezaket, dürüstlük ve saygı gibi ilişkileri ölçümlemektedir. Bies ve Moag (1986) çalışmasında prosedürler uygulandığında insanların deneyimlediği kişilerarası ilişkinin kalitesinin önemine dikkat çekmektedir (Cropanzano vd., 2002: 326). Bu açıdan etkileşim adaletinde endişe edilen husus örgütte kaynak ve ödül tahsisi yapmaktan sorumlu olan kişilerin alıcılara nasıl davrandıklarıdır (Chou, 2009: 72).

\section{2. İş Etiği}

Etik, TDK (2019) tarafından çeşitli meslek kolları arasında tarafların uyması veya kaçınması gereken davranışlar bütünü olarak tanımlamaktadır. Ayrıca etik, ahlakla ilgili olan ayrı bir bilim dalı olarak tanımlanmıştır. Pieper (2012) etiği, ahlaki eylemin bilimi olarak kabul etmektedir. Yazara göre etik insan davranışlarına ilişkin bireysel ahlaki yargılamalarda bulunmaz, birey davranışlarına ilişkin ahlaki çıkarsamalara nasıl ulaşıldığını üst bir bakış açısı ile incelemektedir. Örneğin etik iyi bir davranışın ne olduğunun tanımını yapmaz iyi bir davranışın iyi olduğu sonucuna nasıl ulaşıldığı ile ilgilenmektedir. Cevizci (2002) benzer şekilde ahlaki davranışın eylemin pratiği olduğu yerde etiğin o eyleme ilişkin teoriyi oluşturacağını ifade etmektedir. Literatür etiğin birbirleri ile arasında ilişkileri olan üç farklı türünün olduğunu belirtmektedir. Bunlar betimleyici etik, normatif etik ve meta etiktir. Betimleyici etik, etik olarak kabul edilmesi gereken davranışları belirlemek yerine ahlaki inançlarımıza bağlı olarak gelişen sosyolojik ve psikolojik bir olgularla ilgilenmektedir. Normatif etik ise toplumsal hayatta ve örgütlerde bireylerin nasıl yaşaması gerektiğine dair kurallar koymakta ve normlar belirlemektedir. Normatif etik türü de kendi arasında teolojik ve deontolojik olmak üzere ikiye ayrılmaktadır. Meta etik ise, eleştirisel etik ya da etik ötesi olarak adlandırılmakta ve normatif etik türünün kuralcı yapısına felsefi bir bakış açısıyla yaklaşmaktadır.

Iş hayatında etik ve etikle ilgili öğretilerle ilgilenen disiplin iş etiğidir. İş etiği, bir iş ortamında doğru ya da yanlışı, iyi ya da kötü insan davranışını neyin oluşturduğu ile ilgilenmektedir. İ̧̧ etiği iş hayatında var olan sahtekarlık, rüşvet vb. fiili ve güncel sorunlara karşı evrensel etik ilkelerin uygulanmasıdır. Bu uygulama esnasında iş etiği çalışanlara iş hayatında karşısına çıkan fiili pratik sorunlara etik ilkeler doğrultusunda hangi davranışın "etik" olduğunu belirlemesi ile ilgilenmektedir. Diğer bir ifadeyle çalışana evrensel etik kurallara uygun olarak neyin uygun veya doğru olduğunu düşündürmeyi amaçlamaktadır (Christie vd., 2003: 266). İ̧ etiği kavramının batıdaki gelişimi 1970-1980'li yıllara dayamakla birlikte, Türkiye'de ancak 2000'li yıllarla birlikte önemli gelişmeler yaşandığını söylemek mümkündür. İ̧̧ etiği, etiğin bir alt kümesi olarak çalışma ve 
meslek etiğini de kapsamaktadır. Genel olarak iş etiği işletmelerin ürün ve hizmet üretimi esnasında hem örgüt hem de çalışan düzeyinde davranışların etik boyutu üzerinde yoğunlaşarak bu davranışlara yönelik yol gösteren iş kuralları belirlemeye çalışmaktadır (Arslan ve Berkman, 2019: 15). İ̧̧ etiği, ahlak, politik felsefe, ekonomi, sosyoloji ve sosyal psikoloji gibi çeşitli alanların kavramsal kaynakları üzerine inşa edilmiş melez bir disiplin dalı olarak kabul edilmektedir. Her ne kadar iş etiği kendi başına bir alan olsa da bilim insanları orijinal çalışmalar üretmek için farklı disiplin alanlarından çeşitli teoriler ve fikirler kullanmaya halen devam etmektedirler (Wicks vd., 2019: 155).

\section{3. Örgütsel Adalet ve İş Etiği Kavramları Arasındaki ilişki}

Adalet ve etik ortak köklere ve gelişim kalıplarına sahiptir. Adalet çalışmaları dağıtım adaletinden prosedür ve etkileşim adaletine doğru geliştiği gibi etik araştırmaları da hem prosedürel hem de dağıtım kaygılarını içerecek şekilde genişlemiştir. Etik kavramının kökeninde adaleti, adalet kavramının temelinde etiği görmekteyiz. Normatif etiğin bir alt dalı olan deontolojik etiğin kökeninde adalet ve bireysel hakları yaklaşımı olarak iki temel unsur olduğu belirtilmektedir. Adalet araştırmalarına öncülük eden kuramlarda ise etik ve ahlaki ilkeler özellikle vurgulanmaktadır.

Aslı itibari ile adalet ve etik kavramlarının kökeni Rawls (1971) ortaya koyduğu adalet yaklaşımında bulunmaktadır. Bu yaklaşım deontolojik etik türünün kökenini oluşturmaktadır (Schiminke, 1997). Rawls (1971) adalet teorisinde çalışanların ortaya koyduğu emek ve çabanın karşılığında elde edilen faydanın (ödülün) örgütteki bireyler ve gruplar arasında ne ölçüde eşit dağıtılabildiği sorununa odaklanmıştır. Yazar, bireylerin huzur içinde yaşamlarını sürdürebilmesi için yasal düzenlemelere, kurallara, ilkelere ve uygulamalara ihtiyaç olduğunu, bununla birlikte "eşitliğin eşitsizlik oluşturacağı durumlarda" ise adaleti sağlamak adına elde edilen fayda ve ödülün pozitif ayrımcılık yapılarak dağıtılması gerektiği görüşünü savunmaktadır (Yüksel, 2005:57). Rawls'ın adalet üzerindeki çalışmalarında ortaya koyduğu temel öncülleri ampirik olarak inceleyen Thibaut ve Walker (1975) prosedür adalet teorisini ortaya koymuştur. Örgütsel adalet ve normatif etik türü aynı konuya 'Doğru olan nedir' sorusuna dikkat çekmektedir. Örgütsel adalet çalışmaları, örgütte elde edilen ödüllerin dağııım sürecine (dağıtım adaleti) ve bu sonuçlara ulaşmada karar alma süreçlerine (prosedür adaletine) odaklanmaktadır. Etik araştırmaları benzer şekilde insanların etik olanı belirlemeye çalışırken süreçler ve sonuçlar arasında benzer bir ayrım göz önünde bulundurmaktadır. Bu yaklaşımlar normatif etik türünün bir eylemin etikliğini sonuçlarına göre değerlendiren faydacı (teolojik) etik türüne ve eylemin kendisi üzerinde yoğunlaştığı yaklaşım olan deontolojik etik türüne vurgu yapmaktadır (Schminke vd., 1997: 1190). Cevizci (2002) çalışmasında normatif etik türünün toplumda adaletin tesis edilmesi için var olması gereken unsurları ve sosyal hayatta ulaşılması gereken yüksek değerleri araştırdığını belirtmektedir. Bu hususların hem adalet hem de etik için bir zorunluluk olduğunu ifade etmiştir. Folger vd. (2005) adalet ve etik arasındaki ilişkiyi açıklayan etik kuramın normatif etiğin bir türü olan deontolojik etik olduğunu belirtmiştir.

Prosedür adaleti kavramının temeli olan bir diğer teori adalet yargı teorisi Leventhal (1980) tarafından geliştirilmiş ve dağıtım davranışlarına genel bir model oluşturmayı amaçlamıştır. Bu teoride temel amaç adil uygulamaların gerçekleştirilebilmesi için hangi prosedürlerin kullanılması gerektiğinin bulunmasıdır (Greenberg, 1987: 14-15). Leventhal (1980) adalet yargı teorisinde örgütlerde adil prosedürlerin belirlenebilmesi için 6 temel kural olduğunu belirtmiştir. Bu ilkelerden birisi de alınan kararların etik standartlara uygun olmasıdır. Yazara göre prosedürler, örgüt çalışanlarının sahip olduğu temel ahlaki ve etik değerlerle tutarlı olmalıdır. Bu açıdan şirket prosedürleri ahlaki ilkelere sahip ve kendi içinde tutarlı olmalıdır. Bu kurallar çalışanları hileden, aldatıcı davranıştan, rüşvetten, özel hayatın gizliliğini ihlal etmekten veya rüşvetten kaçındırmalıdır (Dar, 2020: 30). Torlak vd. (2018) tarafından 2427 kişi üzerinde yapılan "Türkiye'de İ̧ Ahlakı Araştırması Nesiller Boyu iş̧ Ahlakı" adlı çalışmada iş dünyasından iş ahlakına uygun davranışların oluşmasında dürüstlükten sonraki en önemli ikinci değerin adalet olduğu tespit edilmiştir. Ayrıca araştırma örnekleminin ahlaki davranışla en çok ilişkilendirdiği kavram ise adalet olmuştur. 


\section{Yöntem}

Araştırmada izlenecek yöntem ve araştırmanın tasarımına ilişkin genel bilgiler Tablo 1'de sunulmaktadır. Araştırma verileri 2019 yılında otuz günlük bir zaman periyodu dahilinde yüz-yüze anket yöntemi kullanılarak elde edilmiştir.

Tablo 1. Araştırmanın Tasarımı

\begin{tabular}{|l|l|}
\hline Araştırmanın Tipi & Betimleyici \\
\hline Araştırmanın Analizi Tekniği & Tümdengelim \\
\hline Araştırma Tarama Modeli & Ilişkisel \\
\hline Örneklem Nüfusu & Özel Sektör Personeli \\
\hline Örneklem Yöntemi & Kolayda Örnekleme \\
\hline Evren & 736 \\
\hline Örneklem Büyüklüğü & 346 \\
\hline Ölçme Aracı & Anket (Beşli Likert tipi değerlendirme ölçeği) \\
\hline Kullanılan İstatiksel Analizler & Yapısal Eşitlik Modeli (YEM) \\
\hline Kullanılan İstatiksel Programlar & SPSS 22.0, AMOS 23.0 \\
\hline
\end{tabular}

\subsection{Araştırmanın Amacı}

Bu araştırmanın amacı algılanan örgütsel adaletin çalışanların iş etiğine yönelik tutumları üzerindeki etkisini tespit etmektir. Bu amaç doğrultusunda araştırmada algılanan örgütsel adalet prosedür, dağıtım ve etkileşim adaleti olmak üzere üç alt boyutta ele alınmıştır.

\subsection{Araştırma Modeli ve Hipotezleri}

Bu çalışmada, adalet ve etik kavramların örtüşen teorik temelleri ve kavramlar arası ilişkileri ortaya koyan nitel ve nicel araştırmaların neticesinde örgütsel adaletin alt boyutları olan prosedür, dağıtım ve etkileşim adaletinin iş etiğine yönelik tutum üzerindeki etkisi araştırılacaktır. Bu amaç doğrultusunda oluşturulan araştırma modeli Şekil 1'de gösterilmektedir.

Şekil 1. Araştırma Modeli

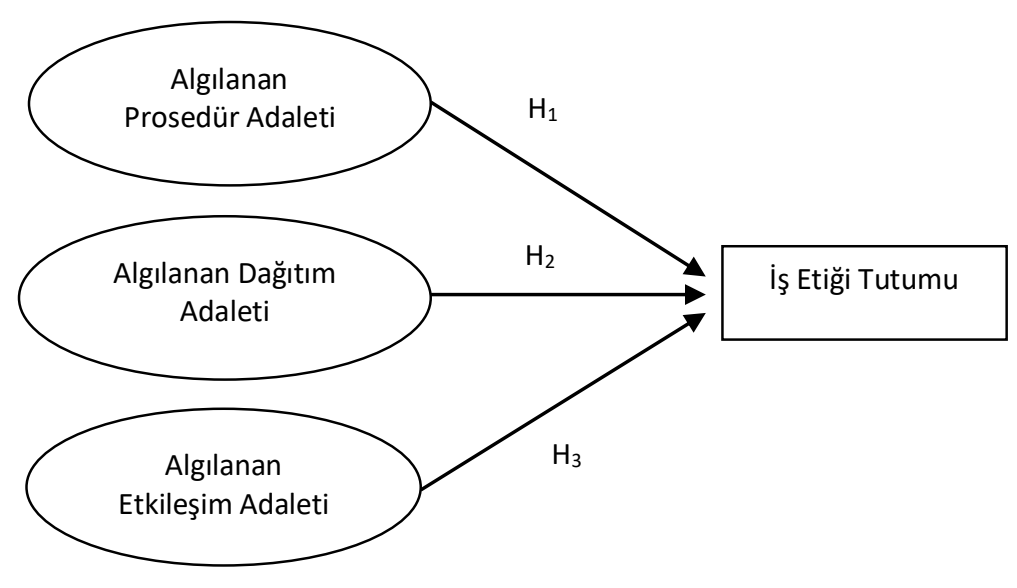


Araştırma modelinde ön görülen etkileri test etmek üzere oluşturulan araştırma hipotezleri şunlardır:

$\mathbf{H}_{1}$ : Algılanan prosedür adaletinin çalışanın iş etiğine yönelik tutumu üzerinde etkisi vardır.

$\mathbf{H}_{2}$ : Algılanan dağıtım adaletinin çalışanın iş etiğine yönelik tutumu üzerinde etkisi vardır.

$\mathbf{H}_{3}$ : Algılanan etkileşim adaletinin çalışanın iş etiğine yönelik tutumu üzerinde etkisi vardır.

\subsection{Araştırma Evreni ve Örneklem}

Araştırma evreni Tokat'ta faaliyet gösteren bir alışveriş merkezinin çalışanlarından oluşmaktadır. Örneklem grubunda yer alan çalışanların, çoğunluğu itibari ile satış elemanı pozisyonunda bulunmaktadır. Araştırma örnekleminin demografik özelliklerine ilişkin bulgular Tablo 2'de sunulmuştur.

Tablo 2. Araştırma Örnekleminin Demografik Özelliklerine Iliş̧in Bulgular

\begin{tabular}{|c|c|c|c|c|c|c|c|}
\hline & & $F$ & $\%$ & & & $F$ & $\%$ \\
\hline \multirow{2}{*}{ Cinsiyet } & Erkek & 233 & 67,3 & \multirow{2}{*}{$\begin{array}{l}\text { Medeni } \\
\text { Durum }\end{array}$} & Evli & 151 & 43,6 \\
\hline & Kadın & 113 & 32,7 & & Bekâr & 195 & 56,4 \\
\hline \multirow{5}{*}{ Yaş } & $21-25$ & 78 & 22,5 & \multirow{3}{*}{ Gelir Düzeyi } & $2020-3000 \mathrm{TL}$ & 280 & $\begin{array}{c}80,9 \\
8\end{array}$ \\
\hline & $26-30$ & 134 & 38,7 & & 3001-4000 TL & 51 & 14,8 \\
\hline & $31-35$ & 86 & 24,9 & & $\begin{array}{l}4001 \text { TL ve üzeri } \\
\text { TL }\end{array}$ & 15 & 4,3 \\
\hline & \multirow[t]{2}{*}{36 ve üzeri } & \multirow[t]{2}{*}{48} & \multirow[t]{2}{*}{13,9} & \multirow{5}{*}{$\begin{array}{l}\text { Çalışma } \\
\text { Süresi }\end{array}$} & 1 yıldan az & 43 & 12,4 \\
\hline & & & & & 1-5 yıl & 218 & 63 \\
\hline \multirow{3}{*}{ Eğitim } & Lise & 29 & 8,4 & & 6-10 yıl & 43 & 12,4 \\
\hline & Ön Lisans & 220 & 63,6 & & 11-15 yıl & 30 & 8,7 \\
\hline & $\begin{array}{l}\text { Lisans ve } \\
\text { Lisansüstü }\end{array}$ & 97 & 28 & & 15 yıldan fazla & 12 & 3,5 \\
\hline
\end{tabular}

Tablo 2'den elde edilen verilere bakıldığında çalışanların çoğunluğu itibari ile erkek personelden oluştuğu $(\% 67,3)$, geneli itibariyle mesleklerinin ilk 5 yılı içerisinde oldukları $(\% 75,4)$ ve gelir düzeylerinin 2019 yılı net asgari ücret seviyesi olan 2020 TL ve 3000 TL arasında değiştiği $(\% 80,9)$ görülmektedir.

\subsection{Veri Toplama Araçları}

Araştırma verilerinin toplanmasında anket yöntemi kullanılmıştır. Anket formunda yer alan sorular $5^{\prime}$ li Likert tipi değerlendirme ölçeğine göre hazırlanmıştır. Araştırmada çalışanların demografik özelliklerini (cinsiyet, medeni durumu, eğitim durumu, gelir düzeyi, yaşı ve çalışma süresi) tespit etmeye yönelik açık ve kapalı uçlu sorular sorulmuştur. Bu aşamadan sonra anket formunda Örgütsel Adalet Ölçeği ve İş Etiğine Yönelik Tutumlar (ATBEQ) ölçeği olmak üzeri iki ölçek kullanılmıştır. Araştırmanın bu kısmında anket formunda yer alan ölçeklere ilişkin gerekli bilgilere, geçerlilik ve güvenilirlik analiz sonuçlarına sırasıyla yer verilmiştir.

Örgütsel Adalet Ölçeği: Araştırmada Niehoff ve Moorman (1993) tarafından geliştirilen "Örgütsel Adalet Ölçeği" kullanılmıştır. Ölçekte, prosedür adaleti için 6 ifade, dağıtım adaleti için 5 ifade, etkileşim adaleti için 9 ifade olmak üzere toplam 20 ifade ve 3 boyut bulunmaktadır. Bu ölçek, Türkiye'de örgütsel davranış araştırmalarında algılanan örgütsel adaletin ölçümü için en sık kullanılan ölçeklerden biridir. Gürbüz ve Mert (2009) tarafından yapılan araştırma neticesinde ölçeğin Türkiye'de yapılacak olan örgütsel adalet ölçümleri için geçerli ve güvenilir bir ölçme aracı olduğu tespiti yapılmıştır. Örgütsel adalet ölçeğinin yapı geçerliliğine tespit etmek amacıyla ikincil düzey doğrulayıcı faktör analizi uygulanmıştır. Yapılan birincil düzey çoklu doğrulayıc faktör analizi sonucunda ölçeğin 3 faktörlü orijinal yapısına benzer bir şekilde dağılım gösterdiği tespit edilmiştir. Yapılan doğrulayıcı faktör analizine ilişkin uyum iyiliği indeks değerleri $p<0,01$ 
anlamlılık düzeyinde x2/df: 2.436, RMSEA: 0,065, NFI: 0,915, CFI: 0,950, GFI: 0,869 olarak tespit edilmiştir. Bu sonuçlara göre ölçeğin uyum iyiliği indeks değerlerinin kabul edilebilir uyum değerlerine sahip olduğu belirlenmiştir. Ölçek boyutlarına ait "Cronbach alfa" katsayıları; Prosedür Adaleti: 0,892, Dağıtım Adaleti: 0,943, ve Etkileşim Adaleti: 0,952 olarak tespit edilmiştir.

İ̧ Etiğine Yönelik Tutum Ölçeği: Bu çalışmada iş etiğine yönelik tutumları ölçmek amacıyla ATBEQ (Altitude Towards Bussiness Ethics Questionarre) "Iş Etiğine Yönelik Tutumlar" ölçeği kullanılmıştır. Bu ölçek ilk olarak Neumann ve Reichel (1987) tarafından geliştirilmiştir. Ölçek Stevens (1979)'un değerleri inceleme araştırması temelinde inşa edilmiştir. Her bir madde için katılımcıdan, bu maddeye ilişkin tutumunu 1 (kesinlikle katılmıyorum) ile 5 (kesinlikle katılıyorum) arasında bir kategoriye işaretleyerek belirtmesi istenmiştir. Ölçek iş etiğine yönelik tutumları ölçmek amacıyla hem dünyada hem de Türk örneklemler üzerinde yapılan araştırmalarda en sık kullanılan veri toplama araçlardan biridir (Erturhan ve Filizöz, 2011; Yıldııım ve Uğuz, 2014; Aksaraylı ve Cevher, 2014; Gözüm, 2016; Sezici ve Kara, 2016; Tunay ve Mercan, 2019). Ölçek makyavelizm, ahlaki nesnellik, kuralcılık, sosyal darwinizm gibi iş felsefesine ait çeşitli ifadeler içermektedir (Preble ve Reichel, 1988). Ölçekte iş etiğine yönelik tutumu ölçmek adına çalışanlara "Etik değerler iş dünyası için anlamsızdır", "Bir çalışan olarak büro malzemelerini eve götürürüm, bu kimseye zarar vermez", "Belirli bir hedefiniz varsa ona ulaşmak için gereken her şey yerine getirilmelidir" vb. ifadelere yer verilmiştir. Ölçeğin yapı geçerliliğini test etmek amacıyla yapılan doğrulayıcı faktör analizi neticesinde yapı geçerliliğini bozan ve faktör yükü düşük 5 ifade ölçekten çıkarılmıştır. Yapılan ikincil düzey doğrulayıcı faktör analizi neticesinde ölçeğin 25 ifade ile tek faktörlü bir dağılım gösterdiği tespit edilmiştir. Yapılan doğrulayıcı faktör analizine ilişkin uyum iyiliği indeks değerleri $p<0,01$ anlamlılık düzeyinde x2/df: 1.911, RMSEA: 0,050, NFI: 0,908, CFI: 0,914, GFI: 0,888 olarak tespit edilmiştir. Bu sonuçlara göre ölçeğin uyum iyiliği indeks değerlerinin kabul edilebilir uyum ve iyi uyum değerlerine sahip olduğu belirlenmiştir. Ölçeğe ait "Cronbach alfa" katsayısı 0,720 olarak tespit edilmiştir. Ölçeğin tek faktörlü dağılım gösterdiğine ilişkin benzer sonuçlar Türk örneklemi üzeri yapılan çeşitli araştırmalarda da görülmektedir (Nurmakhamatuly, 2010).

Ölçeklere yapısal geçerlilik analizi yapıldıktan sonra yakınsak geçerlilik (benzeşim geçerliliği) analizi de yapılmıştır. Yakınsak geçerlilik örgütsel değişkenlere ait ifadelerin birbirleriyle ve meydana getirdikleri faktör ile ilişkili olduklarını ifade eden bir geçerlilik türüdür. Yakınsak geçerliliğin sağlanabilmesi için tüm birleşik güvenirlik (CR) değerinin, ortalama açıklanan varyans (AVE) değerinden büyük olması ve (AVE) değerinin 0,5'ten büyük olması gerekmektedir (Yaşlıoğlu, 2017: 82). Modelde yer alan ölçeklere ait yakınsak geçerliliğinin test edilebilmesi için "Ortalama Açıklanan Varyans (AVE)" değerleri ve Birleşik Güvenirlik (CR) değerleri Tablo 3'te gösterilmektedir.

Tablo 3. Araştırma Ölçeklerine Ait Yakınsal Geçerlilik Analiz Sonuçları

\begin{tabular}{|l|c|c|}
\hline & AVE & CR \\
\hline Algılanan Dağıtım Adaleti & 0,73 & 0,82 \\
\hline Algılanan Etkileşim Adaleti & 0,65 & 0,73 \\
\hline Algılanan Prosedür Adaleti & 0,54 & 0,75 \\
\hline İş Etiğine Yönelik Tutum & 0,57 & 0,74 \\
\hline
\end{tabular}

Elde edilen istatiksel sonuçlar temelinde modelin yakınsak geçerliliği de sağladığı belirlenmiştir.

\section{Bulgular}

Çalışmada araştırma modelini test etmek amacıyla yapısal eşitlik modeli yol analizi uygulanmıştır. Şekil 2'de gösterilen modelde görüldüğü üzere örgütsel adalet birincil düzey doğrulayıcı faktör analizi neticesinde boyutlandırmaları yapılarak 3 alt boyutu ile araştırma modelinde yer almaktadır. Algılanan prosedür adaleti, algılanan dağıtım adaleti ve algılanan etkileşim adaleti faktör analizi sonucunda geçerlilikleri 
tespit edildikten sonra gizil değişkenler olarak araştırma modelinde yer almıştır. Örgütsel adaletin iş etiğine yönelik tutumu hangi boyutta ve ne düzeyde etkilediğinin tespit edilmesinin araştırma sonuçlarına katkı sağlayacağı ve çalışmaya derinlik kazandıracağı düşünülmektedir. Bu açıklamalar neticesinde belirlenen araştırma modeli yapısal eşitlik modeli yol analizi vasıtasıyla test edilmiştir. Yapılan analizler neticesinde araştırma modelinde teorik olarak anlamlı ve modelin uyum iyiliğini yükselten iyileştirmeler (modifikasyonlar) yapılmıştır. Modelin uyum iyiliği değerlerinin p<0,001 anlamlılık düzeyinde (x2/df: 2,140; RMSEA: 0,57; NFI: 0,932; CFI: 0,962; GFI: 0,905) kabul edilebilir uyum ve iyi uyum değerlerine sahip olduğu belirlenmiştir.

Bu aşamadan sonra araştırma hipotezlerini test etmek amacıyla Şekil 2'de gösterildiği üzere yapısal eşitlik modelinde ortaya konan yollara ilişkin analizlere geçilmiştir. Yapılan analizlere ait sonuçlar Tablo 4'de sunulmaktadır.

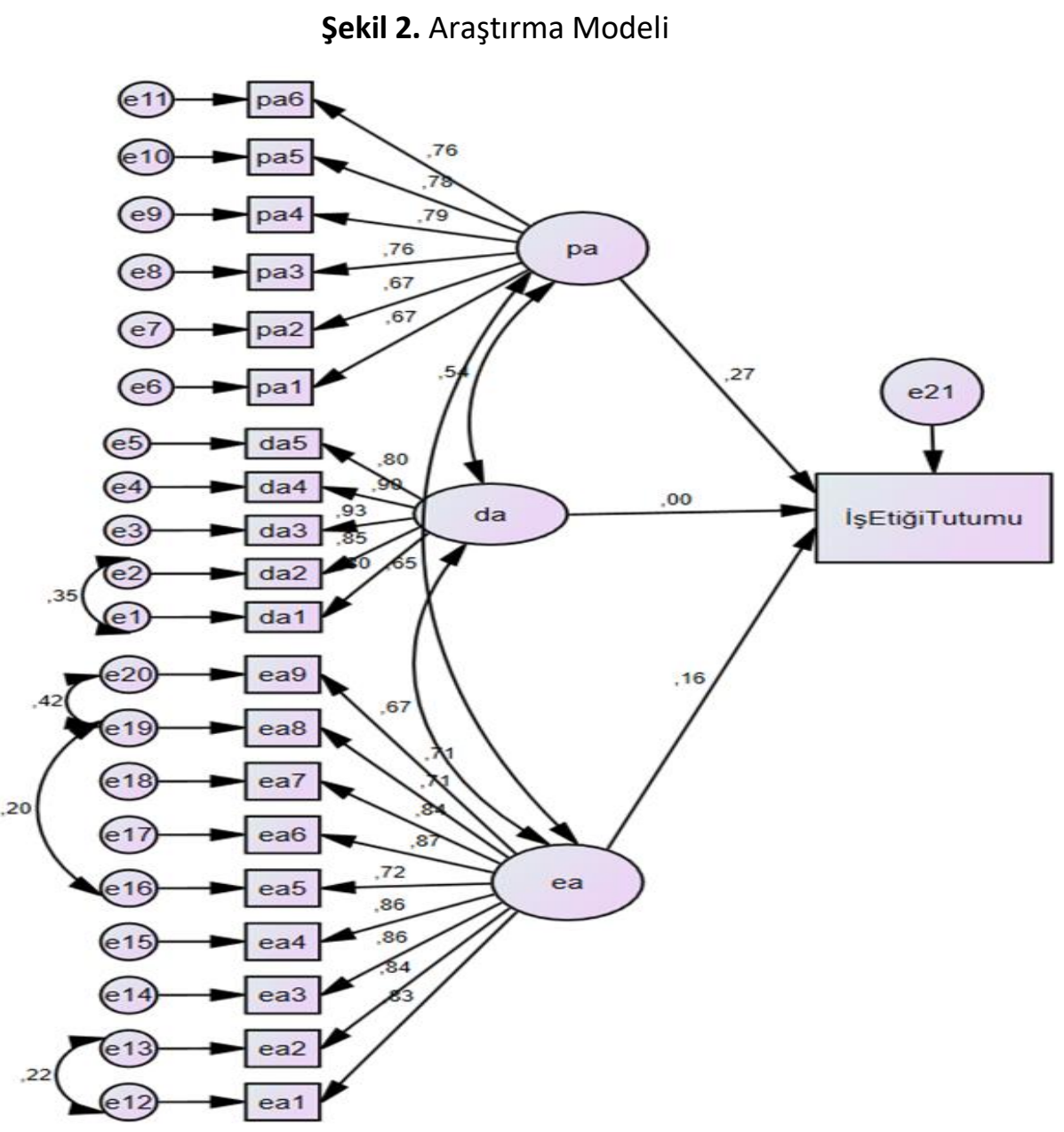

Tablo 4. Araştırma Modeline Ait Yolların Regresyon Ağırlıkları

\begin{tabular}{lcccc}
\hline \multicolumn{1}{c}{ Test Edilen Yol } & & $\begin{array}{l}\text { Standardize } \\
\text { Edilmiş Tahmin }\end{array}$ & (p) \\
\hline İş Etiğine Yönelik Tutum & $<---$ & Algılanan Prosedür Adaleti & 0,269 & $* * *$ \\
İş Etiğine Yönelik Tutum & $<---$ & Algılanan Dağıtım Adaleti & 0,001 & 0,966 \\
İş Etiğine Yönelik Tutum & $<---$ & Algılanan Etkileşim Adaleti & 0,160 & 0,171 \\
\hline$* * *: p<0,001$ & & & &
\end{tabular}


Tablo 4 incelendiğinde $p<0,001$ anlamlılık seviyesinde algılanan prosedür adaletinden iş etiğine yönelik tutuma giden yolun anlamlı olduğu görülmektedir. Modelde yer alan diğer yolların $p<0,05$ anlamlılık seviyesinde anlamsız olduğu tespit edilmiştir. Araştırmada ( $p$ ) anlamlılık değeri $p<0,05$ anlamlılık seviyesinden en uzak olan algılanan dağııım adaletinden iş etiğine yönelik tutuma giden yolun modelden çıkarılması ve modelin tekrar analiz edilmesi neticesinde algılanan etkileşim adaletinden iş etiğine yönelik tutuma giden yolun anlamlı hale gelmediği belirlenmiştir. Bu tespit temelinde iş etiğine yönelik tutum üzerinde algılanan dağııım adaleti ve algılanan etkileşim adaletinin anlamlı bir etkisi olmadığı ortaya konmuştur. Buna bağı olarak araştırmanın bağımsız değişkeni üzerinde etkisi olmayan her iki boyut araştırma modelinden çıkarılarak araştırmanın nihai modeline ulaşılmıştır. Araştırmanın nihai modeli Şekil 3'te gösterilmektedir.

Şekil 3. Araştırma Modeli (Nihai Model)

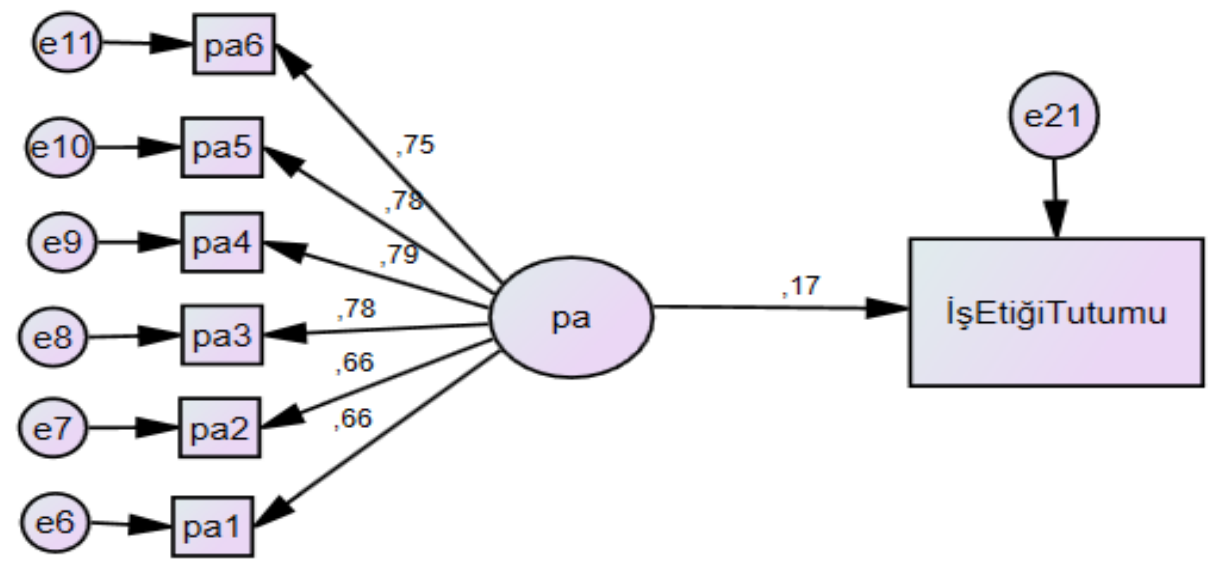

Araştırmanın nihai modelinin uyum iyiliği değerlerinin $p<0,001$ anlamlılık düzeyinde ( $x 2 / d f: 2,861$; RMSEA: 0,73; NFI: 0,959; CFI: 0,972; GFI: 0,967) kabul edilebilir uyum ve iyi uyum değerlerine sahip olduğu belirlenmiştir. Algılanan prosedür adaletinin iş etiği tutumu üzerindeki etkisini belirlemeye yönelik çizilen yapısal eşitlik modeline ait yolun $p<0,004$ anlamlılık düzeyinde $(0,166)$ regresyon ağırlığına sahip olduğu tespit edilmiştir.

\section{Sonuç ve Öneriler}

Çalışmada elde edilen bulgulara bakıldığında algılanan prosedür adaletinin çalışanın iş etiğine yönelik tutumu üzerinde pozitif yönlü etkiye sahip olduğu tespit edilmiştir. $\mathrm{H}_{1}$ hipotezi desteklenmektedir. Algılanan dağıtım ve etkileşim adaletinin çalışanın iş etiği tutumu üzerinde anlamlı bir etkiye sahip olmadığı tespit edilmiştir. $\mathrm{H}_{2}$ ve $\mathrm{H}_{3}$ hipotezleri desteklenmemektedir. Bu sonuçlar temelinde dağıtım adaleti ve etkileşim adalet algısının prosedür adalet algısına göre daha fazla kişi ve bireylerarası ilişki temelli olduğu, bu duruma bağlı olarak çalışanların yer yer objektif değerlendirme sürecinden uzaklaşabildiği söylemek mümkündür (Pitchard, 1969; Colquitt vd., 2001; Markovsky ve Younts, 2001). Çünkü dağıtım adaleti çalışanın iş arkadaşları ile kendini karşılaştırdığı bireysel değerlendirmelere, etkileşim adaleti ise yönetici davranışları temelinde kişilerarası kıyaslamalara dayanmaktadır. Prosedür adaletine baktığımızda ise çalışanın örgütte mevcut karar alma sistemi ve yönetim tarafından alınan yazılı iş prosedürlerinin ve bunların uygulanma sürecine ilişkin adalet değerlendirmesi olduğunu görülmektedir. Ifade edilen bu açıklamalar temelinde çalışanların dağıtım ve etkileşim yönüyle algıladığı adalet ya da adaletsizlik iş etiğine yönelik tutumunu değiştirmezken, eğer adalet ya da adaletsizlik örgütün karar alma sistemine ve yazılı iş prosedürlerine kadar ulaşmışsa çalışanın iş etiğine yönelik tutumu bu durumdan anlamlı bir şekilde etkilenmektedir. Çalışanlar bu süreci adil olarak algılandığında pozitif yönlü bir tutum sergilerken, adaletsiz olarak değerlendirdiklerinde ise negatif yönlü bir tutum sergileyebilmektedir. Bu sonuç belirli düzeyde çalışanların, iş arkadaşları ve yönetici odaklı "kişi” bazlı adalet değerlendirmelerinin etik ve ahlaki tutumlarını etkilemediği, üst yönetim tarafından alınan kararlar ve bu kararların uygulanma sürecinin etik tutum üzerinde önemli bir etkiye sahip olduğunu göstermektedir. 
Örgütsel adalet kavramı üzerine yapılan araştırmalar ortaya koyduğumuz bu sonucu destekler niteliktedir. Croponzano vd. (2002) dağıtım adaleti ile karşılaştırıldığında prosedür adaletinin bir bütün olarak örgüte, üst yönetim ve insan kaynakları sistemlerine tepkilerin daha iyi bir yordayıcısı olma eğiliminde olduğunu belirtmiştir. Prosedür adaleti, bir kararın verildiği sürecin biçimsel yönlerinin bütüncül değerlendirmesi olarak anlaşılırken, etkileşim adaletinin ise bir iş tahsisi sırasında alınan kişilerarası ilişkilerin bir değerlendirmesi olarak anlaşılması gerektiğini belirtmektedir. Benzer şekilde Greenberg (1987) örgütlerde prosedür adalet algısının dağıtım adalet algısından daha güçlü bir etkiye sahip olduğunu, prosedürlerin çalışanlar tarafından adil olarak algılanması ile iş̧̧ilerin adil olmayan iş çıktılarıyla daha az ilgileneceğini ve haksız olanı adil görme eğilimlerinin artabileceğini ifade etmektedir.

Kavramlar arası ilişkilerin ortaya konduğu ortak kökene sahip teorik çalışmalara bakıldığında karşımıza Rawls (1971)'in adalet teorisi, Thibaut ve Walker (1975)'in prosedür adalet teorisi ve Leventhal (1976, 1980) adalet yargı teorileri çıkmaktadır. Bu teorilerin tümü prosedür adaletinin temellerini oluşturmaktadır. Bu durum ortaya konan sonucun teorik temelinin olduğunu ayrıca ortaya koymaktadır.

Literatürde etik ve adalet kavramları ortak köklerinden uzaklaşmaktadır. Örgütsel adalet çalışmaları normatif etik bağlamından çıkarılmakta örgütsel adalet literatüründe ise Rawls (1971)'ın adalet teorisine nadiren referanslar verilmektedir. Bunun aksine neredeyse tüm referansların Adams (1965)'ın eşitlik teorisinde yapıldığı açıkça görülmektedir. Etik literatürüne bakıldığında ise ilgi çeken öncül konuların dağıtım temelinde kaldığı süreçle ilgili konuların azaldığı tespit edilmektedir (Schminke vd., 1997). Ayrıca yapılan saha araştırmalarında $X, Y$ ve $Z$ kuşakları arasında değişen nesillerde adaletçi ahlak anlayışına sahip kişilerin oranın azaldığı belirlenmiştir (Torlak vd., 2018: 91). Bu ifadeler ve tespitler temelinde normatif etik türü (deontolojik etik) ve örgütsel adalet arasındaki ilişkiye ele alan araştırmaların sayısının artırılmasının hem örgütsel davranış bilimine hem de uygulayıcılara faydaları olacağı düşünülmektedir.

Mutlak adaleti yakalamanın mümkün olmadığını bilmekle birlikte örgütlerde artan adalet ve etik sorunlarının, Rawls $(1971,2003)$ 'de ortaya koyduğu adalet anlayışı temelinde, sosyal adalet ilkelerinin iş yerlerinde daha fazla uygulanması ile azalacağını söyleyebilmek mümkündür. Bununla birlikte işletme üst yönetimi karar alma sürecinden önce tam ve doğru bilgiyi sağlamalı, farklı düşüncüleri dinlemelidir. Alınan kararlar ve bunların uygulanma süreci etik ilkeler çerçevesinde tutarlı, tarafsız ve eşit olmalıdır. Karar sonrasında ise işletme itiraz hakkı ve bilgi edinme haklarını çalışanlarına sunmalıdır.

Çalışanların iş etiğindeki düşüşünün daha düşük iş performansı seviyesine neden olduğu (Yandle, 1992) işe devamsızlıkları ve işten ayrılma niyetini artırdığı (Shimko, 1992), örgütsel adanmışlığı azalttığı (Celep vd., 2004), çalışanların yalan söylemelerine ve işe geç gelmeyi adet edinmelerine neden olduğu (Torlak vd., 2018) tespit edilmektedir. Örgütlerde tesis edilecek prosedür adaleti vasıtasıyla çalışanların iş etiğine yönelik tutumları bu durumdan pozitif yönde etkilenecektir. Bu durum iş etiğinin ortaya çıkaracağı olumsuz sonuçlardan hem bireyi hem de örgütünü koruyacaktır.

Çalışmada zaman ve mekân kısıtı nedeniyle belirli bir bölgede ve sınırlı sayıda çalışan araştırma örneklemi olarak belirlenmiştir. Ayrıca araştırma örnekleminin büyük bir çoğunluğunun benzer iş pozisyonlarına sahip olması ve asgari ücret düzeyinde gelir elde etmesi nedeniyle dağıtım adalet algısı ile iş etiğine yönelik tutum arasında kurulan ilişkiyi farklılaştırabileceği ön görülmektedir. Bu durumun testi için farklı bir örneklem kütlesi tercih edilebilir. Örgütsel adalet ve iş etiği arasında aracı rol üstlenebilecek örgütsel değişkenler tespit edilerek farklı araştırmalar yapılabilir. 


\section{Beyan ve Açıklamalar (Disclosure Statements)}

1. Bu çalışmanın yazarı, araştırma ve yayın etiği ilkelerine uyduğunu kabul etmektedir (The author of this article confirms that her work complies with the principles of research and publication ethics).

2. Yazar tarafından herhangi bir çıkar çatışması beyan edilmemiştir (No potential conflict of interest was reported by the author).

3. Bu çalışma, intihal tarama programı kullanılarak intihal taramasından geçirilmiștir (This article was screened for potential plagiarism using a plagiarism screening program).

\section{Kaynaklar}

Adams, J.S. (1965). Inequity in social exchange. (Ed.) L. Berkowitz, Advances in experimental social psychology (2) (pp.267-299). New York: Academic Press.

Aksaraylı, M. F., \& Cevher, E. (2014). Mesleki yükseköğrenimde mesleki etik eğitimine yönelik bir araştırma. Bingöl Üniversitesi Sosyal Bilimler Enstitüsü Dergisi, 4(8), 115-126.

Aleksic, A. (2007). Poslovna etika- element uspješnog Poslovanja. Zbornik Ekonomskog fakulteta u Zagrebu, 5(1), 419429.

Arslan, M., \& Berkman, A. Ü. (2009). Dünyada ve Türkiye'de iş etiği ve etik yönetimi. İstanbul: TÜsiAD Yayınları, Yayın No: TÜsiAD/T-2009-06-492.

Bies, R. J., \& Moag, J. F. (1986). Interactional justice: Communication criteria of fairness. (Ed.) R. J. Lewicki, B. H. Sheppard, \& M. H. Bazerman. Research on negotiations in organizations (pp. 43-55). Greenwich, CT: JAI Press.

Byrne, Z. S., \& Cropanzano, R. (2001). The history of organizational justice: The founders speak. Justice in the Workplace: From Theory to Practice, 2(1), 3-26.

Celep, C., Doyuran, Ş., Sarıdede, U., \& Değirmenci, T. (2004). Eğitim örgütlerinde çok boyutlu iş etiği ve örgütsel adanmışlık. XIII. Ulusal Eğitim Bilimleri Kurultayı, 6-9 Temmuz 2004, İnönü Üniversitesi, Eğitim Fakültesi, Malatya.

Cevizci, A. (2002). Etiğe giriş. i̇stanbul: Paradigma Yayınları.

Chou, R. J. A. (2009). Organizational justice and turnover intention: A study of direct care workers in assisted living facilities for older adults in the United States. Social Development Issues, 31(1), 69-85.

Christie, P. M. J., Kwon, I. W. G., Stoeberl, P. A., \& Baumhart, R. (2003). A cross cultural comparison of ethical attitudes of business managers: India Korea and The United States. Journal of Business Ethics, 46(3), 263-287.

Cohen-Charash, Y., \& Spector, P. E. (2001). The role of justice in organizations: A meta analysis. Organizational Behavior and Human Decision Processes, 86(2), 278-321.

Colquitt, J. A. (2001). On the dimensionality of organizational justice: A construct validation of a measure. Journal of Applied Psychology, 86(3), 386-400.

Cropanzano, R. S., Preher, C. A., \& Chen, P. (2002). Using social exchange theory to distinguish procedural from interactional justice. Group \& Organization Management, 27(3), 324-351

Cropanzano, R. S., \& Ambrose, M. L. (2015). Organizational justice: Where we have been and where we are going. (Ed.) R. S. Cropanzano, \& M. L. Ambrose, The oxford handbook of justice in the workplace (pp.3-14). New York: Oxford University Press.

Dar, M. A. (2020). Organizational justice: The transpiring journey from relative deprivation to integrative justice. The IUP Journal of Organizational Behavior, 19(1), 23-41.

Erturhan, H., \& Filizöz, B. (2011). İş etiği ve bankacılık sektöründe bir araştırma. C.Ü. iktisadi ve idari Bilimler Dergisi, 12(2), 139-157.

Folger, R., Cropanzano, R., \& Goldman, B. (2005). What is the relationship between justice and morality? (Ed.) J. Greenberg \& J. A. Colquitt, Handbook of organizational justice (pp.215-245). London: LEA.

Gözüm, A. G. (2016). Banka çalışanlarının demografik özelliklerine göre iş ahlakı tutumlarının incelenmesi. işletme Araştırmaları Dergisi, 8(2), 293-306

Greenberg, J. (1987). A taxonomy of organizational justice theories. Academy of Management Review, 12(1), 9-22.

Gürbüz, S., \& Mert, í. S. (2009). Örgütsel adalet ölçeğinin geçerlilik ve güvenilirlik uygulaması. Amme Idaresi Dergisi, $42(3), 117-139$. 
Işıkay, Ç. (2019). Yıkıcı örgütsel sapma: Bir Literatür değerlendirmesi. International Social Sciences Studies Journal, 5(50), 6623-6634.

Jawahar, I. M. (2002). A model of organizational justice and workplace aggression. Journal of Management, 28(6), 811834.

Klopotan, I., Aleksić, A., \& Vinković, N. (2020). Do business ethics and ethical decision making still matter: Perspective of different generational cohorts. Business Systems Research, 11(1), 31-43.

Köksal, K. (2018). Örgüt kültürünün örgütsel adalet algısına etkisinde etik ilkelere ilişkin algıların aracılık rolü. Uluslararası Yönetim iktisat ve işletme Dergisi, 14(2), 479-504.

Kurgun, O. A., Aktaş, E., \& Güripek, E. (2013). Çalışanların örgütsel adalet algılarında yöneticilerin etik liderlik davranışlarının rolü. Balıkesir Üniversitesi Sosyal Bilimler Enstitüsü Dergisi, 16(30), 151-166.

Leventhal, G. S. (1980). What should be done with equity theory? (Ed.) K.J. Gergen, M.S. Greenberg, \& R.H. Willis, Social exchange (pp.27-55). Boston, MA: Springer.

Lind, E. A., \& Tyler, T. R. (1988). The social psychology of procedural justice. Springer US.

McGowan, R. (1990). Justice. The root of american business Ideology and ethics. Journal of Business Ethics, 9, 891-901.

Moorman, R. H. (1991). Relationship between organizational justice and organizational citizenship behaviors: Do fairness perceptions influence employee citizenship. Journal of Applied Psychology, 76(6), 845-855.

Niehoff, B. P., \& Moorman, R. H. (1993). Justice as a mediator of the relationship between methods of monitoring and organizational citizenship behavior. Academy of Management Journal, 36(3), 527-556.

Nurmakhamatuly, A. (2010). Kazak ve Türk yöneticilerin iş etiğine ilişkin tutum ve davranışları. İ̧̧ Ahlakı Dergisi, 3(5), 6996.

Park, E. M., \& Seo, J. H. (2019). Effects of shared leadership, psychological empowerment and organizational justice on organizational commitment. Journal of Digital Convergence, 17(6), 177-184.

Oge G., M., Ifeanyi E., O., \& Charles Gozie, A. (2015). Examining the link between organizational justice and counter productive work behaviour. Journal of Business \& Management Studies, 1(1), 1-10.

Pieper, A. (2012). Etiğe giriş (Çev. Veysel Atayman \& Gönül Sezer). İstanbul: Ayrıntı Yayınları.

Preble, J. F., \& Reichel, A. (1988). Attitudes towards business ethics of future managers in the U.S. and Israel. Journal of Business Ethics, (7), 941-949.

Rawls, J. (1971). A theory of justice. Cambridge, MA: Belknap Press.

Rawls, J. (2003). Justice as fairness: A restatement. Cambridge, MA: The Belknap Press Of Harvard University Press.

Sezici, E., \& Kara, H. (2016). İş etiğine ilişkin tutumlar ve başlıca felsefi kategorileri özelinde yönetici-çalışan algısı üzerinde karşılaştırmalı bir inceleme. Anadolu Üniversitesi Sosyal Bilimler Dergisi, Kasım Özel Sayısı, 147-159.

Scandura, T. A. (1999). Rethinking leader-member exchange: An organizational justice perspective. Leadership Quarterly, 10(1), 25-40.

Schminke, M., Ambrose, M. L., \& Noel, T. W. (1997). The effect of ethical frameworks onn perceptions of organizational justice. Acadmey of Journal Management, 40(9), 1190-1207.

Shimko, B. W. (1992). Pre-hire assessment of the new work force: Finding wheat (and work ethic) among the chaff. Business Horizons, 35(3), 60-65.

Skarlicki, D. P., \& Folger, R. (1997). Retaliation in the workplace: The roles of distributive, procedural, and interactional justice. Journal of Applied Psychology, (82), 434-443.

Thibaut, J. W., \& Walker, L. (1975). Procedural justice: A psychological analysis. Hillsdale, N. J.: Lawrence Erlbaum Associates.

Torlak, Ö., Özdemir, Ş., \& Erdemir, E. (2018). Türkiye iş ahlakı araştırması: Nesiller boyu iş ahlakı. İstanbul: i̇GiAD Yayınları.

Türk Dil Kurumu Sözlüğü (2019). https://sozluk.gov.tr/

Wicks, C. A., Werhane, P. H., Thompson, L., \& Bowie, N. (2019). Exploring important thinkers to generate new theory in business ethics. Business Ethics Quarterly, 29(1), 155-157.

Yandle, B. (1992). Does anyone still care? SuperVision, 53, 14-16.

Yaşlıoğlu, M. M. (2017). Sosyal bilimlerde faktör analizi ve geçerlilik: Keşfedici ve doğrulayıcı faktör analizlerinin kullanılması. İstanbul Üniversitesi İ̧̧letme Fakültesi Dergisi, (46), 74-85. 
Yıldırım, M. H., \& Uğuz, Ş. (2012). İş etiği ve üniversite öğrencilerinin etik algılarını ölçmeye yönelik bir araştırma. Organizasyon ve Yönetim Bilimleri Dergisi, 4(1), 177-187.

Yüksel, C. (2005). Devlette etikten etik devlete: Kamu yönetiminde etik kavramsal çerçeve ve uluslararası uygulamalar. Devlette Etik Altyapı Dizisi TÜsiAD Yayınları, Cilt:2, No:1. 